\title{
Reduced salinity, but not estuarine acidification, is a cause of immune-suppression in the Sydney rock oyster Saccostrea glomerata
}

\author{
Timothy J. Green ${ }^{1, *}$, Andrew C. Barnes ${ }^{1,2}$ \\ ${ }^{1}$ The University of Queensland, Centre for Marine Studies, 4072 Brisbane, Queensland, Australia \\ ${ }^{2}$ The University of Queensland, School of Biological Sciences, 4072 Brisbane, Queensland, Australia
}

\begin{abstract}
Acid sulfate soils (ASS) are a major problem around the world. Oxidation of these sulfide-rich sediments by anthropogenic disturbance results in production and release of sulfuric acid. Subsequent rise in the water table due to rain may result in sulfuric acid and heavy metal ions leaching out of the sediments into nearby estuaries, leading to their acidification. Anecdotal evidence exists that flood waters containing ASS leachate may cause adult Sydney rock oysters Saccostrea glomerata to become immune-suppressed, leading to higher mortality rates from the paramyxean parasite Marteilia sydneyi (aetiological agent of QX disease). In the current study, adult S. glomerata were exposed to a seawater matrix of varying salinity, sulfuric acid and $\mathrm{Al}^{3+}$ for $48 \mathrm{~h}$, and the expression of 7 genes involved in immunity were measured by quantitative reverse-transcription polymerase chain reaction. A change in salinity from 35 to 15 ppt caused a 1.7-fold down-regulation in the expression of peroxiredoxin 6 gene $(p<0.05)$. The expression of peroxiredoxin 6 was still down-regulated $5 \mathrm{~d}$ after oysters were returned to full-strength seawater (35 ppt). Changes in salinity, sulfuric acid and $\mathrm{Al}^{3+}$ concentration had no effects on the expression of other target genes $(\mathrm{p}>0.05)$. The effects of salinity, sulfuric acid and $\mathrm{Al}^{3+}$ on the ability of immune genes to respond to microbial invasion were also investigated by exposing oysters to the seawater matrix for $40 \mathrm{~h}$, followed by injection with heat-killed Vibrio alginolyticus bacteria. A drop in salinity coupled with $V$. alginolyticus injection resulted in down-regulation of peroxiredoxin 6 and C1q-like protein $(\mathrm{p}<0.05)$. Apart from C1qlike protein, exposure to sulfuric acid and $\mathrm{Al}^{3+}$ had no significant effects on the response of target genes to stimulation by $V$. alginolyticus ( $p>0.05$ ). These results support that reduced salinity, and not estuary acidification, is the main environmental stressor resulting in $S$. glomerata becoming immunocompromised during the QX disease risk period.
\end{abstract}

KEY WORDS: Oyster · Saccostrea - Gene expression • Acidification - Environmental stress · Acid sulfate soils

\section{INTRODUCTION}

Acid sulfate soils (ASS) have been highlighted as a major problem in Australia and many other areas around the world (Green et al. 2006). Sulfide sediments are formed in vegetated, low-energy tidal environments when sulfate from seawater is reduced to sulfides by microbes. Sulfides react with iron in the sediments to form iron sulfides, primarily pyrite $\left(\mathrm{FeS}_{2}\right)$ and mackinawite (FeS) (Green et al. 2006). Pyrite is stable under anoxic conditions below the water table (Sammut et al. 1996), but on exposure to air, which typically occurs when these sediments are developed for agriculture or urban use, pyrite is oxidized to sulfuric acid (Sammut et al. 1996). Sulfuric acid reacts with clay minerals to release heavy metal ions, principally $\mathrm{Al}^{3+}$ (Macdonald et al. 2007). A rise in the water table or heavy rains can cause acidic and metal-rich waters to leach out of these sediments into estuaries (Russell \& Helmke 2002, Macdonald et al. 2007). Small acid discharges 
into estuaries are neutralized quickly by the alkalinity of seawater. However, after heavy rainfall, acidic floodwaters may at times exceed the neutralizing capacity of the waterway, causing the estuary to become acidified (Russell \& Helmke 2002, Macdonald et al. 2007), which can severely affect the local ecology, biodiversity and economic development of the estuary (Sammut et al. 1995). Fish kills are an immediate and recognizable response to many acidification events. However, there are many direct and indirect impacts of acidification that are more significant than fish kills, but generally less visible.

In northern New South Wales (NSW) and southeast Queensland, Australia, coastal floodplains have been modified through drainage and excavation to facilitate a range of human activities dominated by agriculture and urbanisation (Virgona 1992). Since the completion of extensive drainage canals to mitigate flooding of sugar cane growing areas in 1972, the coastal region of NSW and Queensland has experienced many episodes of estuary acidification after heavy summer rainfall due to ASS leachate (Sammut et al. 1995). Studies have revealed that discharges of acidified water into estuaries from ASS have resulted in fish becoming more susceptible to fungal diseases (Virgona 1992, Callinan et al. 2005) and bacterial infections (Bromage \& Owens 2009). Currently, little is known about the toxicity of $\mathrm{pH}$ and $\mathrm{Al}^{3+}$ exposure levels on the invertebrates native to the estuaries of northern NSW and southeast Queensland.

Sydney rock oysters Saccostrea glomerata are found in temperate and tropical estuaries within Australia and play an important ecological role as filter feeders (Summerhayes et al. 2009). S. glomerata are also the basis of an important aquaculture industry in NSW and southeast Queensland (Nell 2001). Since 1968, mass mortalities of wild and farmed $S$. glomerata have been reported due to the paramyxean parasite Marteilia sydneyi (aetiological agent of QX disease) (Berthe et al. 2004). $M$. sydneyi has at times caused $>98 \%$ mortality on oyster farms in northern NSW and southeast Queensland (Berthe et al. 2004). The disease usually occurs during the summer months, with evidence that mass mortality of $S$. glomerata occurs after summer monsoon rainfall (Lester 1986). A substantial drop in $\mathrm{pH}$ has been recorded after heavy rainfall due to ASS leachate in many estuaries in NSW and Queensland in which QX disease is endemic (Wesche 1995). However, studies have failed to show a correlation between a drop in salinity and/or $\mathrm{pH}$ and the timing of infection of $S$. glomerata with M. sydneyi (Anderson et al. 1994, Wesche 1995). These studies did not examine the synergistic effects of reduced salinity and $\mathrm{pH}$ combined with $\mathrm{Al}^{3+}$ toxicity on host fitness of $S$. glomerata. Changes in $\mathrm{pH}$, heavy metal toxicity and salinity are known to modulate the immune response of bivalves (Parry \& Pipe 2004, Gagnaire et al.
2006, Bibby et al. 2008, Bussell et al. 2008). It is therefore reasonable to expect that exposure of $S$. glomerata to acidified flood waters could compromise the immune system of $S$. glomerata, leading to higher mortality rates of $S$. glomerata when subsequently challenged with $M$. sydneyi. Previous studies have found inhibition of the immunity-associated enzyme phenoloxidase in $S$. glomerata grown in an estuary endemic for QX disease compared to in an estuary where QX disease has never been reported (Peters \& Raftos 2003). Further studies showed that an unknown transient environmental stressor was implicated in $S$. glomerata becoming immune-suppressed during the infective period of $M$. sydneyi in the Hawkesbury River, NSW (Butt \& Raftos 2007). The phenoloxidase activity of $S$. glomerata was measured at several sites within the Hawkesbury River, and the degree of inhibition of the phenoloxidase enzyme correlated with the intensity of infection by $M$. sydneyi (Butt \& Raftos 2007).

The aim of the current study was to determine if changes in salinity and/or ASS leachate affect the expression of immune genes in adult Saccostrea glomerata. The experiment was designed to replicate the effect of a pulse of acidified freshwater entering an estuary after heavy rainfall. Understanding the deleterious impacts of acidified floodwater on the immune system of $S$. glomerata is important, due to the sessile nature, longevity, high abundance and economic value of this species.

\section{MATERIALS AND METHODS}

Animals. Adult 2-yr-old Saccostrea glomerata (mean meat wet weight $6.0 \pm 0.6 \mathrm{~g}$ ) were donated by a commercial oyster farm (Australian Native Shellfish, Wagonga Estuary, NSW). These oysters originated from natural spat-fall caught on hardwood sticks placed in the mouth of the Wagonga Estuary and then transferred upstream to the farm for on-growing to market size. The Wagonga Estuary is considered to be a QXfree zone, as it has never had a reported outbreak of QX disease (Adlard \& Ernst 1995). Oysters were delivered to The University of Queensland by overnight express and immediately placed in a $4000 \mathrm{l}$ seawater recirculating aquarium and fed NOSAN M-1 bivalve diet (Aquasonic) according to the manufacturer's protocol. Oysters were acclimatized for 1 wk before starting experimentation.

Experimental design. Two experiments were conducted to determine the effects of an acidified and $\mathrm{Al}^{3+}$-rich pulse of freshwater entering an estuary after heavy rainfall on the immune system of adult Saccostrea glomerata. The experiments involved exposing 4 groups of $S$. glomerata to a seawater matrix of vary- 
ing water quality characteristics (Table 1) to determine the effects and interactions involved between salinity and ASS leachate. A matrix was chosen as previous experiments on bivalves have shown that the toxicity of a contaminant can be significantly affected by other environmental variables, such as salinity, and extrapolation of these results from a single stressor may portray a misleading picture of immune competence (Parry \& Pipe 2004). The water quality characteristics were chosen as they are environmentally relevant, reflecting previous recordings of estuarine conditions on the east coast of Australia where S. glomerata occur (Wesche 1995, Dove \& Sammut 2007). S. glomerata were exposed to salinities of full strength normal seawater (35 ppt) and brackish water (15 ppt). ASS leachate was replicated by maintaining seawater at a $\mathrm{pH}$ of $6.5 \pm 0.5$ with sulfuric acid and an $\mathrm{Al}^{3+}$ concentration of $1 \mathrm{mg} \mathrm{l}^{-1}$ with $\mathrm{AlK}\left(\mathrm{SO}_{4}\right)_{2} 12 \mathrm{H}_{2} \mathrm{O}$. Normal and brackish seawater was maintained at a pH of $8.0 \pm 0.2$. Seawater was prepared from artificial sea salt (Ocean Nature, Aquasonic) and de-ionised freshwater.

Oysters are known for having a high natural variability in their immune response between individuals. To minimize this variability, some experiments pool individual samples in a treatment to maximise the number of oysters analysed. However, this approach is flawed, as one highly variable individual can influence the results of the pool, possibly resulting in inaccurate conclusions being inferred from the experiment. In the current experiment, individuals were analysed separately so that individual variability could be accounted for.

In the first experiment, 4 groups of Saccostrea glomerata $(\mathrm{N}=16)$ were exposed to the seawater matrix in 1001 aerated static aquaria for a period of $48 \mathrm{~h}$. Four S. glomerata from each treatment were sampled at 24 and $48 \mathrm{~h}$ during the exposure period. At the end of the $48 \mathrm{~h}$ exposure period, the remaining oysters in each treatment $(\mathrm{N}=8)$ were transferred to normal seawater (35 ppt salinity, pH 8.0 and $0 \mathrm{mg} \mathrm{l}^{-1}$ of $\mathrm{Al}^{3+}$ ) to recover for 120 h. Four S. glomerata were also sampled at 24 and $120 \mathrm{~h}$ during the recovery period to determine

Table 1. Saccostrea glomerata. Sydney rock oysters were exposed to a matrix of water with varying salinity, $\mathrm{pH}$ and $\mathrm{Al}^{3+}$ concentrations to determine the interactions and relationships of these water quality variables on the immune system. ASS: acid sulfate soils

\begin{tabular}{|llcccc|}
\hline \multirow{2}{*}{ Normal } & & $\begin{array}{c}\text { Treatment } \\
\text { name }\end{array}$ & $\begin{array}{c}\text { Salinity } \\
\text { (ppt) }\end{array}$ & $\mathrm{pH}$ & $\begin{array}{c}\mathrm{Al}^{3+} \\
\left(\mathrm{mg} \mathrm{l}^{-1}\right)\end{array}$ \\
& Seawater & $35 \mathrm{ppt}$ & 35 & 8.0 & 0 \\
& Brackish & $15 \mathrm{ppt}$ & 15 & 8.0 & 0 \\
ASS & & & & \\
& Seawater & $35 \mathrm{ASS}$ & 35 & 6.5 & 1 \\
& Brackish & $15 \mathrm{ASS}$ & 15 & 6.5 & 1 \\
\hline
\end{tabular}

lasting impacts of the treatments on gene expression. Sampling consisted of taking a hemolymph sample from the adductor muscle using a sterile 21-gauge needle and a $1 \mathrm{ml}$ syringe through a hole previously filed in the left shell valve. The hemolymph sample was immediately centrifuged, and the hemocyte cell pellet resuspended in $250 \mu \mathrm{l}$ of RNAlater (Sigma), incubated for $24 \mathrm{~h}$ at $4^{\circ} \mathrm{C}$ and then stored at $-20^{\circ} \mathrm{C}$ for subsequent quantitative reverse-transcription PCR (qRT-PCR) analysis.

In the second experiment, 4 groups of 8 Saccostrea glomerata were exposed to the seawater matrix in $40 \mathrm{l}$ aerated static aquaria for a period of $40 \mathrm{~h}$. At $40 \mathrm{~h}$, a hole was filed in the left shell valve and $100 \mu$ l of the previously prepared heat-killed Vibrio alginolyticus (Strain 1-50290-P) or phosphate-buffered saline (PBS; as a handling control) was injected into the adductor muscle of 4 oysters per stimulant using a 26-gauge needle and a $1 \mathrm{ml}$ syringe. Oysters were returned to their aquaria for a further $8 \mathrm{~h}$ before taking a hemolymph sample from the adductor muscle and storing the hemocyte cell pellet as above. $V$. alginolyticus was grown overnight in tryptic soy broth containing $2 \%$ $\mathrm{NaCl}$. V. alginolyticus cells were washed 3 times in PBS to remove media and extracellular products, heat inactivated at $70^{\circ} \mathrm{C}$ for $30 \mathrm{~min}$ and resuspended to a final optical density of 1.0 at $600 \mathrm{~nm}$ in PBS (equivalent to $1 \times 10^{9} \mathrm{cell} \mathrm{ml}^{-1}$ ). Although injection of heat-killed $V$. alginolyticus bacteria is not a natural route of infection, this method was chosen as live bacteria can produce extracellular products that inhibit the immune system of their host (Labreuche et al. 2006), masking any potential immune response. Using heat-killed bacteria allows the oyster's immune system to be measured in response to the surface antigens of the bacteria, known as pathogen-associated molecular patterns (PAMPs), without the risk of immune-suppression, whilst still permitting potential encapsulation or phagocytosis of the microorganisms.

RNA purification and qRT-PCR. Total RNA was isolated from hemocyte pellets using the RNeasy kit (Qiagen) following the manufacturer's protocol, with oncolumn DNase digestion using the RNase-free DNase set (Qiagen). The quantity of total RNA purified was determined using a spectrophotometer (Nanodrop ND-1000) at $260 \mathrm{~nm}$, and total RNA was confirmed to be free of DNA contamination by performing a Saccostrea glomerata-specific 18S rDNA PCR (Green et al. 2009). First strand synthesis was performed on $100 \mathrm{ng}$ of total RNA using random hexamer primers and SuperScript III Reverse Transcriptase (Invitrogen) to minimise differences in RT efficiency.

To investigate immune gene expression in oyster circulating hemocytes, we selected $7 \mathrm{cDNA}$ sequences of genes from Saccostrea glomerata that had been previ- 
ously shown to be important in immunity (Green et al. 2009). The GenBank accession numbers for extracellular superoxide dismutase (EcSOD), peroxiredoxin 6 (Prx6), metallothionein (MT), small heat shock protein (sHsP), interferon-inhibiting cytokine (IK), inhibitor of Rel/NF- ${ }_{\kappa} \mathrm{B} \quad\left(\mathrm{I}_{\kappa} \mathrm{B}\right)$ and $\mathrm{C} 1 \mathrm{q}$-like protein (C1q) are FJ626709, FJ626708, GH612255, GH612324, GH612314, GH612349 and GH612251, respectively. The relative expression of the above target genes was determined using the primer pairs listed in Table 2. Primer concentration and amplification efficiency for each primer pair has previously been optimised (Green et al. 2009). Relative expression was normalized by the reference gene, $\beta$-actin. Expression of $\beta$-actin was found to be stable across the different treatments and time points tested in the present study. The cDNA was diluted 10-fold prior to amplification, and each reaction was performed in duplicate. The PCR reaction was performed in a $10 \mu \mathrm{l}$ reaction using SYBR GREEN PCR master mix (Applied Biosystems), $100 \mathrm{nM}$ of each specific primer and $0.2 \mathrm{ng}$ of cDNA in a ABI 7900HT thermocycler (Applied Biosystems) using an initial denaturation step $\left(95^{\circ} \mathrm{C}\right.$, $10 \mathrm{~min}$ ) followed by 45 cycles of a denaturation step $\left(95^{\circ} \mathrm{C}, 15 \mathrm{~s}\right)$ and hybridisation-elongation step $\left(60^{\circ} \mathrm{C}\right.$, $1 \mathrm{~min})$. A subsequent melting temperature curve of the amplicon was performed. Relative expression of the target gene was calculated using the formula: relative expression $=2^{\text {(CTtarget }- \text { CT } \beta \text {-actin) }}$, with the cycle threshold (CT) set at 0.2 for all genes.

Statistical analysis. Two-way ANOVA was used to determine differences in gene expression between different water quality treatments $\times$ time (Expt 1). Oneway ANOVA was used to determine statistical differences in gene expression between oysters injected with Vibrio alginolyticus and those held in different water quality treatments (Expt 2). Differences were considered significant when $\mathrm{p} \leq 0.05$. Tukey's honestly significance difference (HSD) test was used to compare means if significant differences were found. Homogeneity of equal variances was assessed using Levene's test of equal variances and residual plots. If necessary, data were square-root transformed to satisfy the requirements for homogeneity of equal variances. Data are presented as the means $\pm \mathrm{SE}$.

\section{RESULTS}

\section{Effect of water quality on gene expression}

The house-keeping gene, $\beta$-actin, was found to be stable between treatments $(p=0.252)$, thus allowing the comparison of target genes relative to the expression of $\beta$-actin. A rapid change in salinity had a significant effect on the expression of Prx6 in Saccostrea glomerata. Within $24 \mathrm{~h}$ of exposure to brackish water (15 ppt), expression of Prx6 was significantly downregulated by 1.7 -fold ( $p<0.05$ ) when compared to oysters maintained in seawater of 35 ppt. The response kinetics revealed that the expression of Prx6 remained 1.7-fold down-regulated at the $48 \mathrm{~h}$ exposure sample point and was still 1.7-fold down-regulated $120 \mathrm{~h}$ after oysters were returned to normal seawater (35 ppt) to recover. Exposure of $S$. glomerata to water containing sulfuric acid and $\mathrm{Al}^{3+}$ had no significant effects on the expression of Prx6 ( $p>0.05)$. Therefore, the expression of Prx6 is presented relative to treatment (Fig. 1). Exposure to seawater of varying salinity, $\mathrm{pH}$ and $\mathrm{Al}^{3+}$

Table 2. Primer pairs and amplification efficiency of primer sets in real-time quantitative reverse-transcription PCR expression analysis. Tm: predicted primer annealing temperature

\begin{tabular}{|c|c|c|c|c|}
\hline Gene (abbrev.) & Primer sequence $\left(5^{\prime}-\right)$ & $\operatorname{Tm}\left({ }^{\circ} \mathrm{C}\right)$ & Amplicon (bp) & Efficiency \\
\hline Superoxide dismutase (EcSOD) & $\begin{array}{l}\text { AAC TCT ACC ACG GCG AGC AT } \\
\text { CCA CGG TCG TCA TCA TGA AG }\end{array}$ & $\begin{array}{l}58 \\
59\end{array}$ & 76 & 2.0 \\
\hline Peroxiredoxin 6 (Prx6) & $\begin{array}{l}\text { GAA GGA TGG AAG GAC GGT GAT } \\
\text { CAC CTG TGG AAA CAC CTT CTC }\end{array}$ & $\begin{array}{l}59 \\
59\end{array}$ & 82 & 1.9 \\
\hline Interferon-inhibiting cytokine (IK) & $\begin{array}{l}\text { AAC TGT TTT TAC CGG GAC GTA TG } \\
\text { GGT ACA GGG CAC GTC ATT CTC }\end{array}$ & $\begin{array}{l}58 \\
58\end{array}$ & 77 & 2.0 \\
\hline Small heat shock protein (sHsP) & $\begin{array}{l}\text { GAG AAT TCA CCA AGT CCT ACA CAC TTC } \\
\text { CGC CAT CTC TGG ACA ACG TT }\end{array}$ & $\begin{array}{l}59 \\
60\end{array}$ & 78 & 2.0 \\
\hline Metallothionein (MT) & $\begin{array}{l}\text { AAG AAG AAT GCC TGC CAC ATG } \\
\text { GGA TGG ACA GGA TTG AAA TTC C }\end{array}$ & $\begin{array}{l}59 \\
58\end{array}$ & 76 & 2.0 \\
\hline Inhibitor of Rel/NF- ${ }_{k} \mathrm{~B}\left(\mathrm{I}_{\kappa} \mathrm{B}\right)$ & $\begin{array}{l}\text { TCG CGA TTC TCG GTG TTT C } \\
\text { GGA CAC GGC ACT TCA TAT TGC }\end{array}$ & $\begin{array}{l}58 \\
59\end{array}$ & 79 & 1.9 \\
\hline C1q-like protein (C1q) & $\begin{array}{l}\text { TCT TCT CTC GAG GTA TTC CGA ATG } \\
\text { CAG CTG TAA ATC CCA CCT TTT TG }\end{array}$ & $\begin{array}{l}60 \\
59\end{array}$ & 76 & 2.0 \\
\hline$\beta$-actin & $\begin{array}{l}\text { GTA TTG CTG ACC GTA TGC AGAAAG } \\
\text { GGT GGA GCA ATG ACC TTG ATC }\end{array}$ & $\begin{array}{l}59 \\
58\end{array}$ & 76 & 2.0 \\
\hline
\end{tabular}




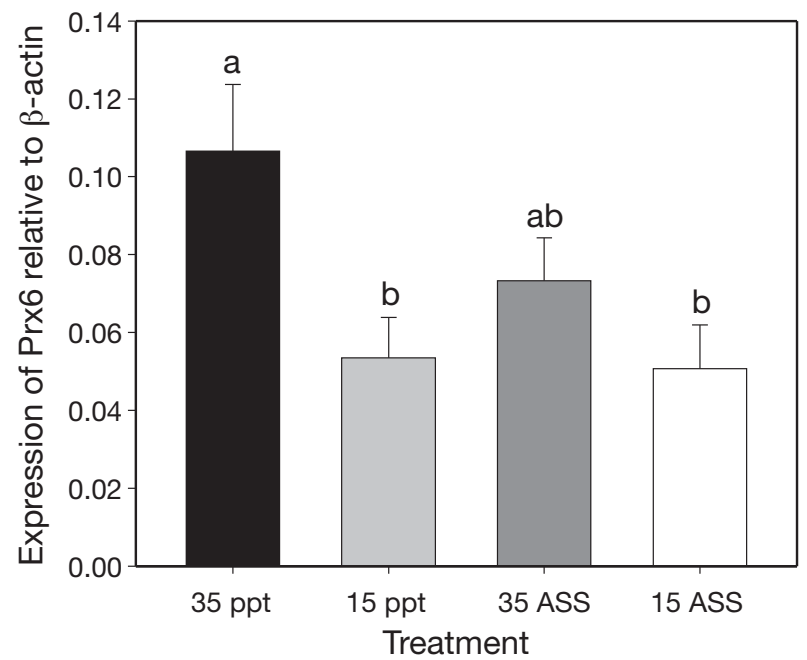

Fig. 1. Saccostrea glomerata. Relative expression of peroxiredoxin (Prx6) in $S$. glomerata exposed to water of varying salinity, $\mathrm{pH}$ and $\mathrm{Al}^{3+}$ concentrations. No effect of time was observed $(p>0.05$, ANOVA); thus, data are presented according to treatment (average of all sample points). Expression is presented relative to the expression of the reference gene, $\beta$-actin (mean $\pm \mathrm{SE}$ ). Different letters above bars indicate significant differences between treatments ( $p<0.05$, ANOVA). ASS: acid sulfate soils. See Table 1 for treatment abbreviations and details

concentrations had minor effects on the expression of sHsP in S. glomerata. At 24 h exposure, a general trend was that lower salinity caused an elevation in the expression of $\mathrm{sHsP}$, whilst sulfuric acid and $\mathrm{Al}^{3+}$ caused expression of sHsP to be depressed. Although these trends were insignificant ( $\mathrm{p}>0.05)$, a significant 4.2fold down-regulation of $\mathrm{sHsP}$ was observed for $S$. glomerata exposed to seawater of 35 ppt containing sulfuric acid and $\mathrm{Al}^{3+}$ when compared to brackish water of $15 \mathrm{ppt}$ at the $24 \mathrm{~h}$ time-point ( $<$ < 0.05) (Fig. 2). The response kinetics revealed that by $48 \mathrm{~h}$ exposure, no significant differences were observed for expression of sHsP between different treatments for the remainder of the trial ( $p>0.05$ ) (Fig. 2). Water quality had no significant effect on the expression of EcSOD, IK, MT, I B, or C1q in S. glomerata (p > 0.05) (data not presented).

\section{Effect of Vibrio alginolyticus bacteria on the immune system of Saccostrea glomerata}

The effect of heat-killed $V$. alginolyticus bacteria on the immune system of $S$. glomerata was investigated by comparing the expression of target genes in oysters maintained in normal seawater and injected with either $V$. alginolyticus or PBS. Injection of $V$. alginolyticus did not affect the expression of the house-keeping gene, $\beta$-actin $(p=0.157)$. The injection of $V$. alginolyti-

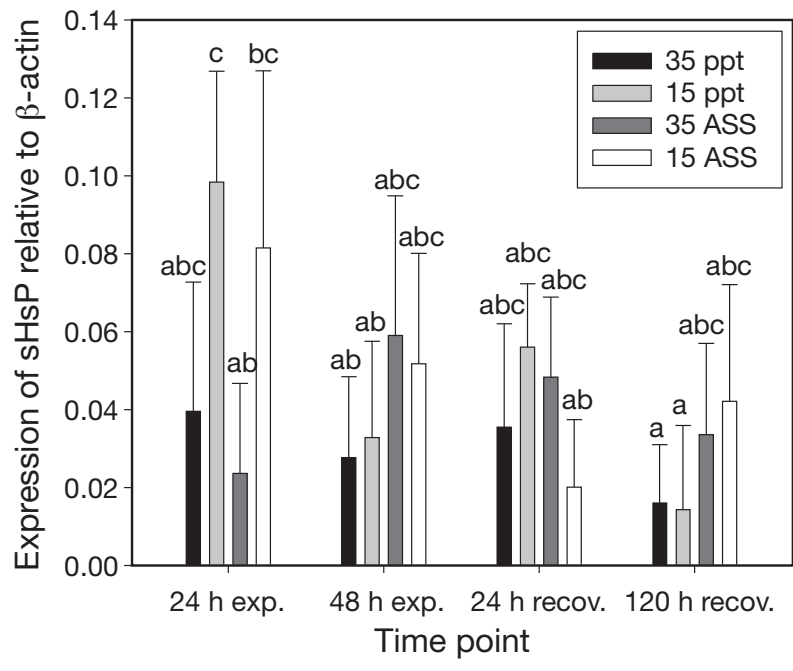

Fig. 2. Saccostrea glomerata. Relative expression of small heat shock protein (sHsP) in $S$. glomerata exposed to water of varying salinity, $\mathrm{pH}$ and $\mathrm{Al}^{3+}$ concentrations. At the end of the $48 \mathrm{~h}$ exposure period, $S$. glomerata were transferred to normal seawater and the relative expression of sHsP was measured at 24 and $120 \mathrm{~h}$ post treatment. At $24 \mathrm{~h}$ of exposure, a significant 4.2 -fold difference was observed in the relative expression of sHsP between $S$. glomerata exposed to seawater of $35 \mathrm{ppt}$ containing sulfuric acid and $\mathrm{Al}^{3+}$ when compared to brackish water of $15 \mathrm{ppt}(\mathrm{p}<0.05)$. No significant differences were observed in the relative expression of $\mathrm{sHsP}$ between the different treatments for the remainder of the trial ( $p>0.05)$. Expression is presented relative to the expression of the reference gene, $\beta$-actin (mean $\pm \mathrm{SE}$ ). Different letters above bars indicate significant differences between treatments $(p<0.05$, ANOVA). See Table 1 for treatment abbreviations and details

cus induced 3.2-fold higher relative expression of $\mathrm{I}_{\kappa} \mathrm{B}$ than in PBS-injected oysters ( $<$ < 0.05) (Fig. 3A). In contrast, injection of $V$. alginolyticus down-regulated the expression of $\mathrm{C} 1 \mathrm{q}$ by 6.5 -fold compared to in PBS controls $(\mathrm{p}<0.05)$ (Fig. 3B). Injection of $V$. alginolyticus had no effect on the expression of EcSOD, Prx6, IK, sHsP, or MT when compared to PBS-injected control oysters $(p>0.05)$ (data not presented).

\section{Interaction of water quality and Vibrio alginolyticus on gene expression}

The expression of the house-keeping gene, $\beta$-actin was found to be stable in oysters exposed to the seawater matrix and injected with $V$. alginolyticus bacteria $(p=0.782)$. To account for the change in expression of target genes due to handling and injection, the relative expression of target genes in Saccostrea glomerata injected with $V$. alginolyticus was calculated by subtracting the relative expression of target genes from S. glomerata injected with PBS. Interactions of salinity and $\mathrm{pH}$ were found to have a significant effect on the 

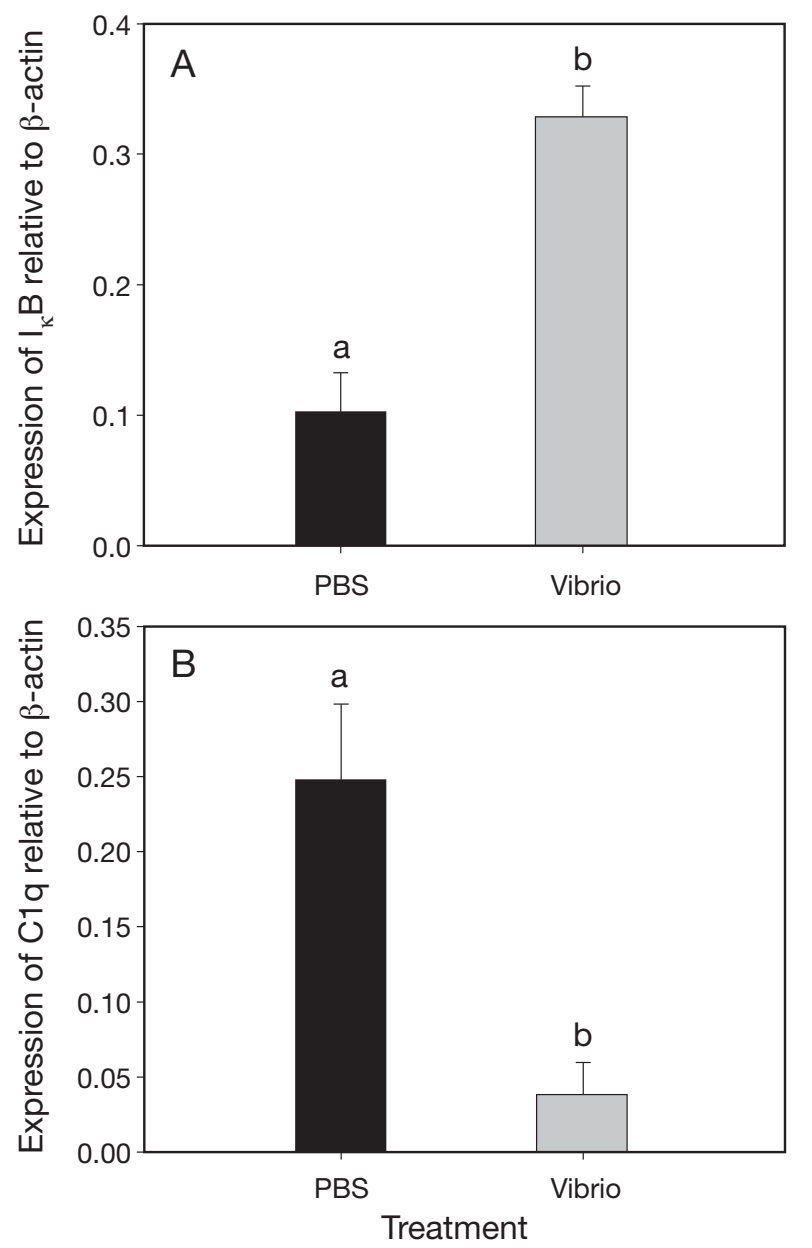

Fig. 3. Saccostrea glomerata. Relative expression of (A) $I_{\kappa} B$ and (B) C1q (see Table 2) in S. glomerata held in normal seawater (see Table 1) and injected with either heat-killed Vibrio alginolyticus bacteria or phosphate-buffered saline (PBS; handling control). Expression is presented relative to the expression of the house-keeping gene, $\beta$-actin (mean $\pm \mathrm{SE}$ ). Different letters above bars indicate significant differences between treatments $(p<0.05$, ANOVA)

expression of EcSOD ( $\mathrm{p}<0.01)$, Prx6 ( $\mathrm{p}<0.05)$ and C1q (p < 0.01) in $S$. glomerata injected with $V$. alginolyticus bacteria. A significant difference was observed in the expression of EcSOD between oysters exposed to brackish water of $15 \mathrm{ppt}$ when compared to brackish water of 15 ppt containing ASS leachate ( $p<0.05)$. However, a change in salinity or $\mathrm{pH}$ did not significantly change the expression of EcSOD from seawater controls ( $p>0.05$ ) (Fig. 4A). A significant difference in the expression of Prx6 was observed between oysters exposed to seawater (35 ppt) and brackish water (15 ppt), with Prx6 down-regulated by 5.1-fold ( $\mathrm{p}<$ 0.05) (Fig. 4B). No significant effect of sulfuric acid and $\mathrm{Al}^{3+}$ was observed on the expression of Prx6 ( $\left.\mathrm{p}>0.05\right)$. A drop in salinity caused a 1.18-fold down-regulation
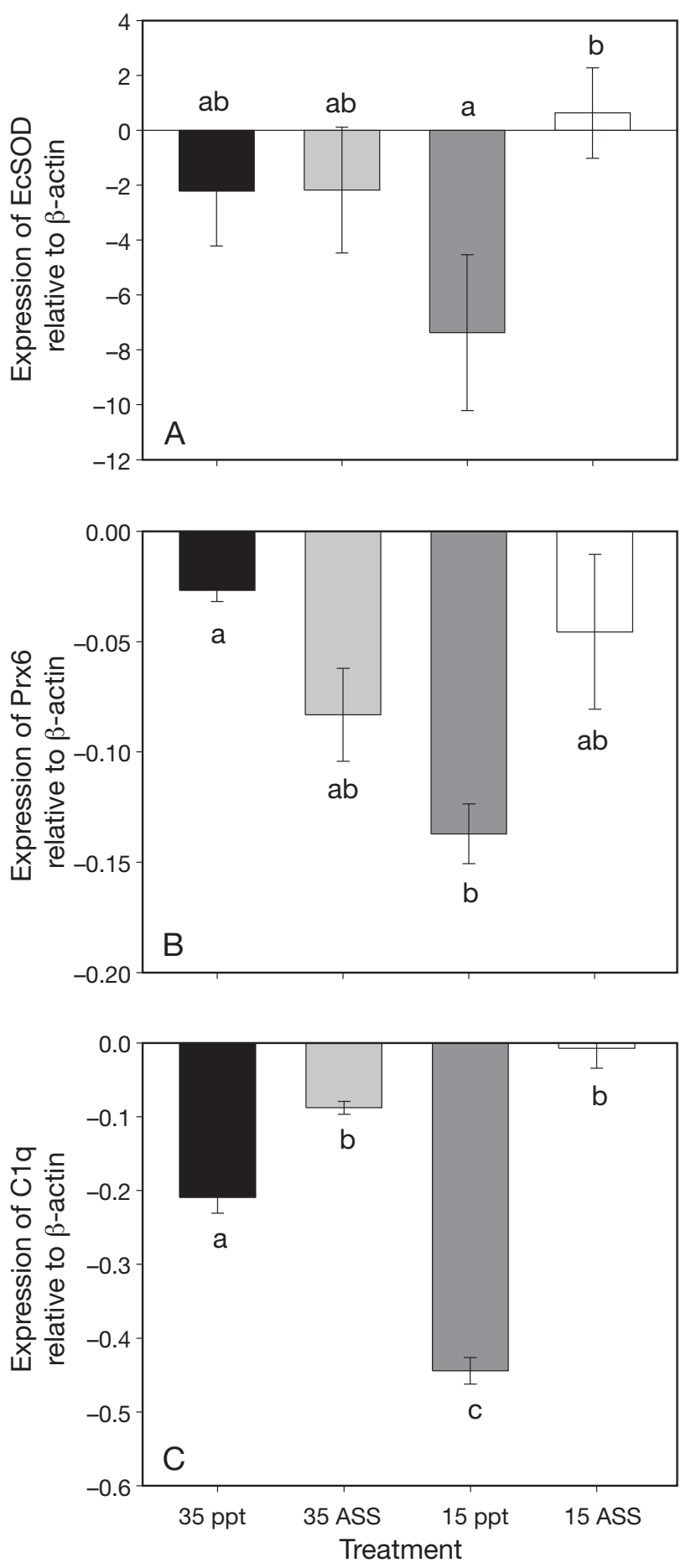

Fig. 4. Saccostrea glomerata. Relative expression of (A) EcSOD, (B) Prx6 and (C) C1q (see Table 2) in S. glomerata injected with Vibrio alginolyticus bacteria and exposed to water of varying salinity, $\mathrm{pH}$ and $\mathrm{Al}^{3+}$ concentrations. Expression of target genes is presented relative to the expression of the house-keeping gene ( $\beta$-actin) minus the expression of target genes of $S$. glomerata injected with phosphate-buffered saline (handling controls). Different letters above bars indicate significant differences between treatments $(p<0.05$, ANOVA). See Table 1 for treatment abbreviations and details 
in the expression of $\mathrm{C} 1 \mathrm{q}$, and exposure to sulfuric acid and $\mathrm{Al}^{3+}$ caused a 1.09-fold and 1.13-fold up-regulation in the expression of C1q in $S$. glomerata injected with $V$. alginolyticus and exposed to a salinity of 35 and $15 \mathrm{ppt}$, respectively ( $\mathrm{p}<0.05$ ) (Fig. $4 \mathrm{C}$ ). No effect of salinity, sulfuric acid, or $\mathrm{Al}^{3+}$ was observed on the relative expression of $\mathrm{IK}, \mathrm{sHsP}, \mathrm{I}_{\mathrm{K}} \mathrm{B}$, or $\mathrm{MT}(\mathrm{p}>0.05)$.

\section{DISCUSSION}

In the present study, the effect of ASS leachate on the expression of immune genes in Saccostrea glomerata was studied by exposing $S$. glomerata to a seawater matrix of varying salinity, sulfuric acid and $\mathrm{Al}^{3+}$. Changes in water chemistry affected the expression of genes involved in stress and detoxification (Prx6 and $\mathrm{sHsP})$, but not those involved in immunity (IK, $\mathrm{I}_{\mathrm{\kappa}} \mathrm{B}$ and C1q). The Prx6 gene encodes for a non-selenium glutathione peroxidase (Almar et al. 1998) and is highly regulated in bivalves in response to environmental disturbance (David et al. 2007, Park et al. 2008). The expression of Prx6 has been shown to be correlated with environmental pollution in the Pacific oyster Crassostrea gigas (David et al. 2007) and increasing temperature stress in the Antarctic bivalve Laternula elliptica (Park et al. 2008). The down-regulation of the S. glomerata Prx6 gene in response to a drop in salinity (Fig. 1) suggests that heavy monsoon rainfall causes sustained immune-suppression and stress in S. glomerata. The sHsP gene encodes for a small heat shock protein (HSP), and numerous forms of inducible and constitutive HSPs have been identified in oysters (Tirard et al. 1995, Clegg et al. 1998). Inducible HSPs are expressed during stressful periods, such as elevated temperature or osmotic changes, and act as molecular chaperones to rescue damaged proteins, thereby helping to conserve the pool of existing proteins from irreversible damage (Parsell \& Lindquist 1993). The interaction of salinity and ASS leachate had a minor but complex effect on the expression of sHsP, with changes in the expression of sHsP observed at $24 \mathrm{~h}$ exposure to reduced salinity and ASS leachate (Fig. 2). The expression of sHsP had returned to normal within $48 \mathrm{~h}$, suggesting that ASS leachate has minimal influence on the basal-expression of immune and stress genes in $S$. glomerata.

Previous studies have shown that some environmental toxicants may not cause mortality of bivalves on their own, but act synergistically with bivalve pathogens to cause mortality (Anderson et al. 1998, Gagnaire et al. 2007). When the eastern oyster Crassostrea virginica, naturally infected with Perkinsus marinus, was exposed to the pollutant tributylin and hypoxia, tributylin alone did not affect mortality of $C$. virginica from $P$. marinus, but hypoxia exacerbated the effect of this toxicant and increased mortality synergistically with tributylin (Anderson et al. 1998). To explore the possible synergistic interaction of acidic floodwaters and microbial invasion on the immune-competence of Saccostrea glomerata, oysters were injected with heatkilled Vibrio alginolyticus, as QX disease cannot be replicated in the laboratory due to the complex life cycle of Marteilia sydneyi (Kleeman et al. 2002). Injection of $V$. alginolyticus bacteria caused an up-regulation of $\mathrm{I}_{\mathrm{K}} \mathrm{B}$ and a down-regulation of $\mathrm{C} 1 \mathrm{q}$ in oysters maintained in seawater (Fig. 3A,B). Up-regulation of $I_{\kappa} B$ in response to $V$. alginolyticus injection is consistent with previous studies (Green \& Barnes 2009, Zhang et al. 2009) and suggests activation of the Rel/NF- ${ }_{\kappa} \mathrm{B}$ pathway (Karin \& Ben-Neriah 2000, Montagnani et al. 2008). The Rel/NF- ${ }_{\kappa} \mathrm{B}$ pathway is involved in the transcription of numerous inducible genes involved in immune function and inflammation (Baeuerle \& Baltimore 1996). The biological function of C1q in oysters is currently unknown, but is commonly identified in oyster expressed sequence tags libraries (Jenny et al. 2002, Rafferty \& Powell 2002, Green et al. 2009, Taris et al. 2009). The constitutive expression of C1q was found to be lower in family lines of $C$. gigas that show higher tolerance to environmental stress (Taris et al. 2009), but no difference was observed in the constitutive expression of C1q between $S$. glomerata bred for resistance or susceptibility to QX disease (Green et al. 2009). In other organisms, the C1q domain-containing proteins are known to participate in inflammation, adaptive immunity and energy homeostasis (Kishore $\&$ Reid 2000).

Exposure of Saccostrea glomerata to seawater with either a reduced salinity, reduced $\mathrm{pH}$ or reduced salinity and $\mathrm{pH}$ followed by injection with Vibrio alginolyticus bacteria had no effect on the expression of $\mathrm{I}_{\kappa} \mathrm{B}$ when compared to seawater controls, suggesting the tested water quality variables had no effect on the Rel/ $\mathrm{NF}_{{ }_{\kappa}} \mathrm{B}$ pathway. However, changes in water chemistry and injection with $V$. alginolyticus bacteria caused changes in expression of $S$. glomerata Prx6 and C1q compared to seawater controls (Fig. 4B,C). Although the biological function of bivalve $\mathrm{C} 1 \mathrm{q}$ is currently unknown, it is likely to be involved in defence (Kishore \& Reid 2000), and changes in its expression as a result of reduced salinity or ASS leachate are likely to have detrimental outcomes for the host during infection. Previous studies have also observed interactions of environmental toxicants and pathogens on gene-regulation in oysters (Gagnaire et al. 2007). Mortality of the Pacific oyster Crassostrea gigas, when exposed to pesticide and Vibrio splendidus, was attributed to over-regulation of immune genes resulting in host tissue damage (Gagnaire et al. 2007). When the plasma membrane of oyster he- 
mocytes comes into contact with pathogens, a range of reactive oxygen intermediates (ROIs) are generated for the cytotoxic killing of these invading micro-organisms (Adema et al. 1993, Hampton et al. 1998). ROIs such as superoxide anion and hydrogen peroxide $\left(\mathrm{H}_{2} \mathrm{O}_{2}\right)$ are also toxic to host tissue (e.g. cause DNA damage, lipid peroxidation). In molluscs, the Prx6 enzyme scavenges $\mathrm{H}_{2} \mathrm{O}_{2}$ and provides protection against $\mathrm{H}_{2} \mathrm{O}_{2}$-induced cell apoptosis (Nikapitiya et al. 2009). Down-regulation of the Prx6 gene in $S$. glomerata due to reduced salinity prior to infection with Marteilia sydneyi could possibly result in higher mortality of $S$. glomerata from $\mathrm{H}_{2} \mathrm{O}_{2}$-induced damage to host tissue. This is consistent with previous studies linking hyposalinity with reduced immune function. Extensive research has implicated the involvement of the phenoloxidase enzyme in the survival of $S$. glomerata during M. sydneyi infection (Newton et al. 2004, Bezemer et al. 2006, Butt \& Raftos 2008), and inhibition of the phenoloxidase enzyme has been observed in S. glomerata during the QX-disease risk period (Peters \& Raftos 2003, Butt \& Raftos 2007). A drop in salinity from 34 to $13.5 \mathrm{ppt}$ for $12 \mathrm{~d}$ or longer has been linked with inhibition of the phenoloxidase enzyme (Butt et al. 2006).

Prolonged exposures or exposure to lower $\mathrm{pH}$ and higher $\mathrm{Al}^{3+}$ concentration may have had a greater impact on gene expression in Saccostrea glomerata. In the upper reaches of the Tweed, Clarence and Richmond Rivers, which are rock oyster farming estuaries in northern NSW, studies have been conducted measuring the water chemistry during times of heavy rainfall; the salinity, $\mathrm{pH}$ and $\mathrm{Al}^{3+}$ concentrations recorded were $5 \mathrm{ppt}, 3.0$ units and $40 \mathrm{mg} \mathrm{l}^{-1}$, respectively (Virgona 1992, Sammut et al. 1995, 1996, Macdonald et al. 2007). However, the current experiment was designed to replicate the environmental perturbations that farmed $S$. glomerata would be exposed to in their estuarine habitat. S. glomerata are usually farmed in the lower reaches of estuaries where the tidal cycle would rapidly buffer $\mathrm{pH}$ changes and dilute toxic heavy metals resulting from ASS leachate (Dove \& Sammut 2007). Previous studies have measured the changes in $\mathrm{pH}$ in estuaries adjacent to oyster farms throughout the summer to determine the environmental variability (Anderson et al. 1994, Wesche 1995, Dove \& Sammut 2007). The Pimpama River in southeast Queensland is reported to have yearly mass mortalities of $S$. glomerata caused by Marteilia sydneyi (Kleeman et al. 2002), and the $\mathrm{pH}$ of this river is reported to be above $\mathrm{pH} 7.8$, except during times of heavy rainfall, when flood water causes the pH to fall to as low as pH 6.5 (Wesche 1995). The relatively small impact of the tested water quality variables on immune-gene expression in adult S. glomerata was unexpected and may reflect the fact that adult oysters are intertidal euryhaline organisms that have evolved mechanisms to cope with rapid changes in their environment. The juvenile finfish Pagrus auratus, Acanthopagrus australis and Macquaria novemaculeata and the marine invertebrate prawn Metapenaeus macleayi can predict acidity and avoid low concentrations of sulfuric acid ( $\mathrm{pH} 6.6$ to 5.0) when given a choice (Kroon 2005). Adult S. glomerata are sessile organisms that cannot escape ASS leachate, but are likely to close their shells in an attempt to avoid the acidity and heavy metal toxicity associated with ASS leachate. The effects of salinity, sulfuric acid and $\mathrm{Al}^{3+}$ toxicity on immune-gene expression in larval and juvenile (spat) $S$. glomerata was not tested in the current study, but is likely to be more pronounced, indeed, salinity and ASS leachate both have a significant effect on the survival of juvenile and larval $S$. glomerata (Dove \& O'Connor 2007, Dove \& Sammut 2007).

Previous studies have reported that there is no relationship between acidic floodwaters and the timing of QX disease outbreaks (Anderson et al. 1994, Wesche 1995). Acidic and $\mathrm{Al}^{3+}$-rich water had minor influence on the expression of immune-related genes in the present study. However, the current study provides further evidence that reduced salinity as a result of monsoon rainfall causes adult Saccostrea glomerata to become immune-suppressed by altering the activity of oxidative enzymes important in immunity.

Acknowledgements. The authors acknowledge D. Maidment for the donation of oysters. The authors also acknowledge the Australian Government for the Australian Postgraduate Award to T. Green.

\section{LITERATURE CITED}

Adema CM, van Deutekom-Mulder EC, van der Knaap WPW, Sminia T (1993) NADPH-oxidase activity: the probable source of reactive oxygen intermediate generation in hemocytes of the gastropod Lymnaea stagnalis. J Leukoc Biol 54:379-383

Adlard RD, Ernst I (1995) Extended range of the oyster pathogen Marteilia sydneyi. Bull Eur Assoc Fish Pathol 15: 119-121

Almar M, Otero L, Santos C, González Gallego J (1998) Liver glutathione content and glutathione-dependent enzymes of two species of freshwater fish as bioindicators of chemical pollution. J Environ Sci Health B 33:769-783

Anderson RS, Wesche SJ, Lester RJG (1994) Are outbreaks of Marteilia sydneyi in Sydney rock oysters, Saccostrea commercialis, triggered by a drop in environmental $\mathrm{pH}$ ? Aust J Mar Freshwater Res 45:1285-1287

Anderson RS, Brubacher LL, Ragone Calvo L, Unger MA, Burreson EM (1998) Effects of tributyltin and hypoxia on the progression of Perkinsus marinus infections and host defence mechanisms in oyster, Crassostrea virginica (Gmelin). J Fish Dis 21:371-379

- Baeuerle PA, Baltimore D (1996) NF-kB: ten years after. Cell $87: 13-20$

> Berthe FCJ, Roux FL, Adlard RD, Figueras A (2004) Marteiliosis in molluscs: a review. Aquat Living Resour 17:433-448 
Bezemer B, Butt D, Nell JA, Adlard RD, Raftos DA (2006) Breeding for QX disease resistance negatively selects one form of the defensive enzyme, phenoloxidase, in Sydney rock oysters. Fish Shellfish Immunol 20:627-636

Bibby R, Widdicombe S, Parry H, Spicer J, Pipe R (2008) Effects of ocean acidification on the immune response of the blue mussel Mytilus edulis. Aquat Biol 2:67-74

Bromage E, Owens L (2009) Environmental factors affecting the susceptibility of barramundi to Streptococcus iniae. Aquaculture 290:224-228

Bussell JA, Gidman EA, Causton DR, Gwynn-Jones D and others (2008) Changes in the immune response and metabolic fingerprint of the mussel, Mytilus edulis (Linnaeus) in response to lowered salinity and physical stress. J Exp Mar Biol Ecol 358:78-85

Butt D, Raftos DA (2007) Immunosuppression in Sydney rock oysters (Saccostrea glomerata) and QX disease in the Hawkesbury River, Sydney. Mar Freshw Res 58: 213-221

Butt D, Raftos DA (2008) Phenoloxidase-associated cellular defence in the Sydney rock oyster, Saccostrea glomerata, provides resistance against QX disease infections. Dev Comp Immunol 32:299-306

Butt D, Shaddick K, Raftos DA (2006) The effect of low salinity on phenoloxidase activity in the Sydney rock oyster, Saccostrea glomerata. Aquaculture 251:159-166

Callinan RB, Sammut J, Fraser GC (2005) Dermatitis, branchitis and mortality in empire gudgeon Hypseleotris compressa exposed naturally to runoff from acid sulfate soils. Dis Aquat Org 63:247-253

Clegg JS, Uhlingher KR, Jackson SA, Cherr GN, Rifkin E, Friedman CS (1998) Induced thermotolerance and the heat shock protein-70 family in the Pacific oyster Crassostrea gigas. Mol Mar Biol Biotechnol 7:21-30

David E, Tanguy A, Moraga D (2007) Peroxiredoxin 6 gene: a new physiological and genetic indicator of multiple environmental stress response in Pacific oyster Crassostrea gigas. Aquat Toxicol 84:389-398

- Dove MC, O'Connor WA (2007) Salinity and temperature tolerance of Sydney rock oysters Saccostrea glomerata during early ontogeny. J Shellfish Res 26:939-947

Dove MC, Sammut J (2007) Impacts of estuarine acidification on survival and growth of Sydney rock oysters, Saccostrea glomerata (Gould, 1850). J Shellfish Res 26: 519-527

Gagnaire B, Frouin H, Moreau K, Thomas-Guyon H, Renault $\mathrm{T}$ (2006) Effects of temperature and salinity on hemocyte activities of the Pacific oyster, Crassostrea gigas (Thunberg). Fish Shellfish Immunol 20:536-547

Gagnaire B, Gay M, Huvet A, Daniel JY, Saulnier D, Renault T (2007) Combination of a pesticide exposure and a bacterial challenge: in vivo effects on immune response of Pacific oyster, Crassostrea gigas (Thunberg). Aquat Toxicol 84: 92-102

- Green TJ, Barnes AC (2009) Inhibitor of REL/NF-kB is regulated in Sydney rock oysters in response to specific double-stranded RNA and Vibrio alginolyticus, but the major immune anti-oxidants EcSOD and Prx6 are non-inducible. Fish Shellfish Immunol 27:260-265

Green R, Waite DT, Melville MD, Macdonald BCT (2006) Characteristics of the acidity in acid sulfate soil drainage waters, McLeods Creek, Northeastern NSW, Australia. Environ Chem 3:225-232

- Green TJ, Dixon TJ, Devic E, Adlard RD, Barnes AC (2009) Differential gene expression of antioxidant enzymes in Sydney rock oysters, Saccostrea glomerata (Gould) selected for disease resistance. Fish Shellfish Immunol 26:
$799-810$

> Hampton MB, Kettle AJ, Winterbourn CC (1998) Inside the neutrophil phagoxome: oxidants, myeloperoxidase, and bacterial killing. Blood 92:3007-3017

Jenny MJ, Ringwood AH, Lacy ER, Lewitus AJ and others (2002) Potential indicators of stress response identified by expressed sequence tag analysis of hemocytes and embryos from the American oyster, Crassostrea virginica. Mar Biotechnol 4:81-93

Karin M, Ben-Neriah Y (2000) Phosphorylation meets ubiquitination: the control of NF-kB activity. Annu Rev Immunol 18:621-663

> Kishore U, Reid KB (2000) C1q: structure, function, and receptors. J Immunopharmacol 49:159-170

- Kleeman SN, Adlard RD, Lester RJG (2002) Detection of the initial infective stages of the protozoan parasite Marteilia sydneyi in Saccostrea glomerata and their development through to sporogenesis. Int J Parasitol 32:767-784

Kroon FJ (2005) Behavioural avoidance of acidified water by juveniles of four commercial fish and prawn species with migratory life stages. Mar Ecol Prog Ser 285:193-204

Labreuche Y, Soudant P, Goncalves M, Lambert C, Nicolas JL (2006) Effects of extracellular products from the pathogenic Vibrio aestuarianus strain 01/32 on lethality and cellular immune responses of the oyster Crassostrea gigas. Dev Comp Immunol 30:367-379

Lester RJG (1986) Field and laboratory observations on the oyster parasite Marteilia sydneyi. In: Cremin M, Dobson C, Moorhouse DE (eds) Parasite lives. University of Queensland Press, Brisbane, p 33-40

Macdonald BCT, White I, Astrom ME, Keene AF, Melville MD, Reynolds JK (2007) Discharge of weathering products from acid sulfate soils after a rainfall event, Tweed River, eastern Australia. Appl Geochem 22:2695-2705

Montagnani C, Labreuche Y, Escoubas JM (2008) Cg-IkB, a new member of the IkB protein family characterised in the Pacific oyster Crassostrea gigas. Dev Comp Immunol 32: 182-190

Nell JA (2001) The history of oyster farming in Australia. Mar Fish Rev 63:14-25

- Newton K, Peters R, Raftos DA (2004) Phenoloxidase and QX disease resistance in Sydney rock oysters (Saccostrea glomerata). Dev Comp Immunol 28:565-569

Nikapitiya C, De Zoysa M, Whang I, Kim CG, Lee YH, Kim SJ, Lee J (2009) Molecular cloning, characterization and expression analysis of peroxiredoxin 6 from disk abalone Haliotis discus discus and the antioxidant activity of its recombinant protein. Fish Shellfish Immunol 27:239-249

Park H, Ahn IY, Kim H, Cheon J, Kim M (2008) Analysis of ESTs and expression of two peroxiredoxins in the thermally stressed Antarctic bivalve Laternula elliptica. Fish Shellfish Immunol 25:550-559

Parry HE, Pipe RK (2004) Interactive effects of temperature and copper on immunocompetence and disease susceptibility in mussels (Mytilus edulis). Aquat Toxicol 69: 311-325

- Parsell DA, Lindquist S (1993) The function of heat-shock proteins in stress tolerance: degradation and reactivation of damaged proteins. Annu Rev Genet 27:437-496

Peters R, Raftos DA (2003) The role of phenoloxidase suppression in QX disease outbreaks among Sydney rock oysters (Saccostrea glomerata). Aquaculture 223:29-39

> Rafferty GP, Powell R (2002) Identification of genes expressed in the gill tissue of the Pacific oyster (Crassostrea gigas) using expressed-sequence tags. J Molluscan Stud 68: 397-399

Russell DJ, Helmke SA (2002) Impacts of acid leachate on 
water quality and fisheries resources of a coastal creek in northern Australia. Mar Freshw Res 53:19-33

Sammut J, Melville MD, Callinan RB, Fraser GC (1995) Estuarine acidification: impacts on a aquatic biota of draining acid sulfate soils. Aust Geogr Stud 33:89-100

Sammut J, White I, Melville MD (1996) Acidification of an estuarine tributary in eastern Australia due to drainage of acid sulfate soils. Mar Freshw Res 47:669-684

Summerhayes SA, Kelaher BP, Bishop MJ (2009) Spatial patterns of wild oysters in the Hawkesbury River, NSW, Australia. J Shellfish Res 28:447-451

Taris N, Lang RP, Reno PW, Camara MD (2009) Transcriptome response of the Pacific oyster (Crassostrea gigas) to infection with Vibrio tubiashii using cDNA AFLP differential display. Anim Genet 40:663-677

Editorial responsibility: Otto Kinne,

Oldendorf/Luhe, Germany
Tirard CT, Grossfeld RM, Levine J, Kennedy-Stoskopf S (1995) Effect of hyperthermia in vitro on stress protein synethesis and accumulation in oyster hemocytes. Fish Shellfish Immunol 5:9-25

- Virgona JL (1992) Environmental factors influencing the prevalence of a cutaneous ulcerative disease (red spot) in the sea mullet, Mugil cephalus L., in the Clarence River, New South Wales, Australia. J Fish Dis 15:363-378

Wesche SJ (1995) Outbreaks of Marteilia sydneyi in Sydney rock oysters and their relationship with environmental $\mathrm{pH}$. Bull Eur Assoc Fish Pathol 15:23-27

Zhang D, Jiang S, Qiu L, Su T and others (2009) Molecular characterization and expression analysis of the IkB gene from pearl oyster Pinctada fucata. Fish Shellfish Immunol 26:84-90

Submitted: August 18, 2009; Accepted: November 23, 2009 Proofs received from author(s): March 1, 2010 